\title{
The life cycle of Myxobolus lentisuturalis (Myxozoa: Myxobolidae), from goldfish (Carassius auratus auratus), involves a Raabeia-type actinospore
}

\author{
Monica Caffara ${ }^{1}$, Elena Raimondi ${ }^{1}$, Daniela Florio ${ }^{1}$, Federica Marcer $^{2}$, Francesco Quaglio ${ }^{3}$ \\ and Maria Letizia Fioravanti ${ }^{1}$
}

\author{
${ }^{1}$ Department of Veterinary Public Health and Animal Pathology, Alma Mater Studiorum University of Bologna, via Tolara di Sopra \\ 50, 40064 Ozzano Emila (Bologna), Italy; \\ ${ }^{2}$ Department of Experimental and Veterinary Sciences, University of Padova, Agripolis - Viale dell’Università 16, 35020 Padova, \\ Italy; \\ ${ }^{3}$ Department of Public Health, Comparative Pathology and Veterinary Hygiene, University of Padova, Agripolis - Viale \\ dell'Università 16, 35020 Padova, Italy
}

\begin{abstract}
We studied a natural infection of the oligochaete Branchiura sowerbyi Beddard, 1892 with the Raabeia-type actinosporean stage of Myxobolus lentisuturalis Dyková, Fiala et Nie, 2002 which infected goldfish Carassius auratus auratus (L.) in Italy, using molecular analysis of the SSU rRNA gene. The existence of intraoligochaete development shows that this parasite follows the lifecycle pattern described by Wolf and Markiw (1984) for Myxobolus cerebralis. Histological examinations of the goldfish infected by $M$. lentisuturalis showed at low magnification the presence of two bilateral crescent-shaped masses in the dorsal epaxial muscle. These lesions were not circumscribed, presented irregular edges and infiltrated the underlying bundles of skeletal muscle and interstitial tissue. At higher magnification, disappearance of muscle fibres and substitution of the muscle tissue with Myxobolus spores and plasmodia were observed.
\end{abstract}

Key words: Myxosporea, Myxobolus lentisuturalis, actinospore, Raabeia-type, life cycle, Carassius auratus auratus, Branchiura sowerbyi, Italy

Myxobolus lentisuturalis Dyková, Fiala et Nie, 2002 was first described by Dyková et al. (2002) as a highly pathogenic myxozoan infecting the muscles of Prussian carp, Carassius gibelio Bloch in China. Some aspects of its development within the fish host were studied by the above-mentioned authors but they provided no data on putative extrapiscine developmental stage.

Since the intraoligochaete developmental phase of Myxobolus cerebralis Hofer, 1903 was first described by Wolf and Markiw (1984), several other authors have supported the hypothesis that the development of other myxosporeans is also accomplished through oligochaete and fish alternate hosts. Thus far, complete developmental cycles have been described for 14 Myxobolus species (Table 1). Recent studies have shown that, besides oligochaetes, polychaetes (Bartholomew et al. 1997, 2006, Køie et al. 2004, 2007, 2008) and bryozoans (Longshaw et al. 1999, Kent et al. 2000) can also serve as alternate hosts for fish myxozoans.

The alternate actinospore and myxospore life cycle stage of a given myxozoan species can be identified by experimental infection studies in both fish and inverte-
Table 1. Myxobolus species with completely known developmental cycles (Lom and Dyková 2006).

\begin{tabular}{|c|c|c|}
\hline Myxosporean stage & $\begin{array}{l}\text { Actinosporean } \\
\text { stage }\end{array}$ & Authority \\
\hline Myxobolus cerebralis & Triactinomyxon & Wolf and Markiw 1984 \\
\hline M. cotti & Triactinomyxon & $\begin{array}{l}\text { El-Matbouli and } \\
\text { Hoffmann } 1989\end{array}$ \\
\hline M. carassii & Triactinomyxon & $\begin{array}{l}\text { El-Matbouli and } \\
\text { Hoffmann } 1993\end{array}$ \\
\hline M. arcticus & Triactinomyxon & Kent et al. 1993, Urawa 1994 \\
\hline M. drjagini & Triactinomyxon & El-Mansy and Molnár 1997a \\
\hline M. hungaricus & Triactinomyxon & El-Mansy and Molnár 1997b \\
\hline M. portucalensis & Triactinomyxon & El-Mansy et al. 1998 \\
\hline M. bramae & Triactinomyxon & Eszterbauer et al. 2000 \\
\hline M. pseudodispar & Triactinomyxon & Székely et al. 2001 \\
\hline M. macrocapsularis & Triactinomyxon & Székely et al. 2002 \\
\hline M. parviformis & Triactinomyxon & Kallert et al. 2005 \\
\hline M. pavlovskii & Hexactinomyxon & Ruidisch et al. 1991 \\
\hline M. cultus & Raabeia & Yokoyama et al. 1995 \\
\hline M. dispar & Raabeia & $\begin{array}{l}\text { Molnár et al. } 1999, \\
\text { Holzer et al. } 2004\end{array}$ \\
\hline
\end{tabular}

brate hosts or by analysis of DNA sequences from both stages. Several authors recommend the inclusion of DNA sequences in the identification of actinospores (El-Mansy 
et al. 1998, Hallett et al. 1999, Negredo et al. 2003), and SSU rRNA sequences have been used successfully for the confirmation of heteroxenous life cycles in several studies (Andree et al. 1997, Bartholomew et al. 1997, 2006, Anderson et al. 1999, 2000, Lin et al. 1999, Køie et al. 2004, 2007, 2008, Atkinson et al. 2007).

In Italy, goldfish Carassius auratus auratus (L.) farming has been a traditional activity since the end of the 1800 's, with a current production of more than 25 million fish per year. Myxozoan parasites described in farmed goldfish in Italy include Sphaerospora renicola, S. molnari and Zschokkella sp. (Marcer et al. 2000) but, until now, no Myxobolus infection has been reported.

In this paper, we report a muscle infection caused by Myxobolus lentisuturalis in goldfish farmed in Italy. Morphological and molecular analyses of this species, as well as data on the histopathological damage in goldfish and on its extrapiscine development in the oligochaete, Branchiura sowerbyi Beddard, 1892, is provided.

\section{MATERIALS AND METHODS}

Fish. Twenty-eight goldfish (C. auratus auratus), displaying dorsolateral humps $(2 \times 1 \mathrm{~cm})$, from a pond farm in the province of Bologna (Italy) underwent parasitological examination. The contents of the humps were collected with a sterile syringe and examined microscopically, both fresh and stained with MayGrünwald-Giemsa. The humps were excised and fixed in $10 \%$ neutral buffered formalin along with the gills, gut and kidney. Tissue samples were embedded in paraffin and the sections were stained with haematoxylin and eosin (H\&E), Giemsa, Periodic Acid Schiff (PAS), Ziehl-Neelsen and Crossmonn's trichrome stain. Spore measurements were taken from the fresh material $(\mathrm{n}=50)$ under the light microscope with the aid of a camera lucida, and are given in micrometres $(\mu \mathrm{m})$ as the mean followed by the range and standard deviation (SD) in parentheses. Species description followed the criteria established by Lom and Arthur (1989).

DNA extraction and PCR. Total spore DNA was extracted with a spin column purification procedure (DNeasy Tissue Kit, Qiagen, Valencia, CA) following the manufacturer's protocol. The SSU rRNA gene was amplified with the universal eukaryotic primer pair (forward 5'-AYCTGGTTGATYYTGCCAG-3' and reverse 5'-TGATCCATCTGCAGGTTCACCT-3') (Embley et al. 1992). The total volume of the PCR reaction was $50 \mu 1$, containing 10× PCR buffer (Invitrogen), $25 \mathrm{mM}$ dNTPs (Invitrogen), $50 \mathrm{pmol} / \mu \mathrm{l}$ of each primer, $1.5 \mathrm{mM} \mathrm{MgCl}_{2}$ and $1.25 \mathrm{U}$ Taq DNA Polymerase (Invitrogen). A Tpersonal (Biometra) thermocycler was used for the amplification. The reactions consisted of 35 cycles of $30 \mathrm{sec}$ at $94{ }^{\circ} \mathrm{C}, 30 \mathrm{sec}$ at $55^{\circ} \mathrm{C}$ and 1.5 min at $72{ }^{\circ} \mathrm{C}$, preceded by a denaturation step at $94^{\circ} \mathrm{C}$ for $2 \mathrm{~min}$ and followed by an extended elongation step at $72{ }^{\circ} \mathrm{C}$ for 10 min. The PCR products were electrophoresed in $1 \%$ agarose gel (Sigma) and stained with Sybr Safe DNA Gel Stain $0.5 \times$ TBE (Molecular Probes, Invitrogen).

PCR products were cloned into the pCR 2.1 TOPO Cloning vector using the TOPO TA Cloning Kit (Invitrogen). Plasmid DNA was isolated from each clone using a Quantum Prep-Plasmid Miniprep Kit (BioRad) following the manufac- turer's procedure. The presence of the insert of the expected size was confirmed by restriction digestion analysis with the EcoRI enzyme. Ten positive clones were sequenced (PRIMM, Milano, Italy) in both directions using M13 Forward (-20) (5'-GTAAAACGACGGCCAG-3') and M13 Reverse (5'-CAGGAAACAGCTATGAC-3') primers (Invitrogen) in an ABI 3730 DNA Analyzer. Sequence assembling was carried out using Vector NTI Advance ${ }^{\mathrm{TM}} 10$ software (Invitrogen), and underwent a database search using BLAST (Altschul et al. 1990).

Oligochaetes. To define the life cycle of this parasite and identify the possible alternate hosts, a survey of invertebrates at the goldfish farm was carried out. Mud samples were collected in mid-October both from the bottom of the pond and from the decantation tank, and transported to the laboratory. The oligochaetes were washed from the mud, sorted by size and placed in small aerated aquaria with dechlorinated tap water and sterile sand. They were kept at room temperature and fed with dried spirulina. The water covering the worms was filtered once a week through $20 \mu \mathrm{m}$ mesh and the filtrate collected in a drop of water and examined for the presence of actinospores. Once spores were seen in the main sample of water, one-hundred oligochaetes were isolated and kept individually in the wells of cell-well plates according to Yokoyama et al. (1991). Each well was examined for the presence of released actinospores every $3 \mathrm{~d}$ for two months, using an inverted microscope. Actinospores released were studied by microscopy and PCR, and the SSU rRNA products were cloned and sequenced as described above.

The oligochaetes releasing actinospores were fixed in $10 \%$ neutral buffered formalin, embedded in paraffin and stained with H\&E and Giemsa.

The oligochaetes were identified morphologically according to the key of Brinkhurst and Jamieson (1971).

\section{RESULTS}

\section{Morphology of myxospore}

Fig. 1

The mature spores collected from the goldfish were ellipsoidal with symmetrical shell valves, an indistinct sutural ridge, a conspicuous intercapsular process and the sporoplasm occupying the posterior half of the spore body. The average length of fresh spores was 10.5 (9.0-11.0 \pm $0.6)$, the width was $6.6(6.0-7.0 \pm 0.4)$ and the thickness was $3.9(3.0-5.0 \pm 0.8)(\mathrm{n}=50$ from one host $)$. Two equal anteriorly-tapered pyriform polar capsules were located at the anterior part of the spore. The anterior ends of the polar capsules were separated 1.5-2 from each other; polar filaments were coiled 4-5 times. The average length of the polar capsule was $3.7(3.0-4.5 \pm 0.4)$ and the width was $2.2(2.0-3.0 \pm 0.3)(\mathrm{n}=100)$. Pseudocysts, composed of several plasmodia measuring up to 70 and filled with developing spores, were observed subcutaneously in the superficial lateral muscle. The spores were identified as Myxobolus lentisuturalis on the basis of morphometry and morphology.

\section{Morphology of actinospore}

Fig. 2

Actinospores were released from only one of the worm biotypes (18 subjects), later identified as Branchiura 

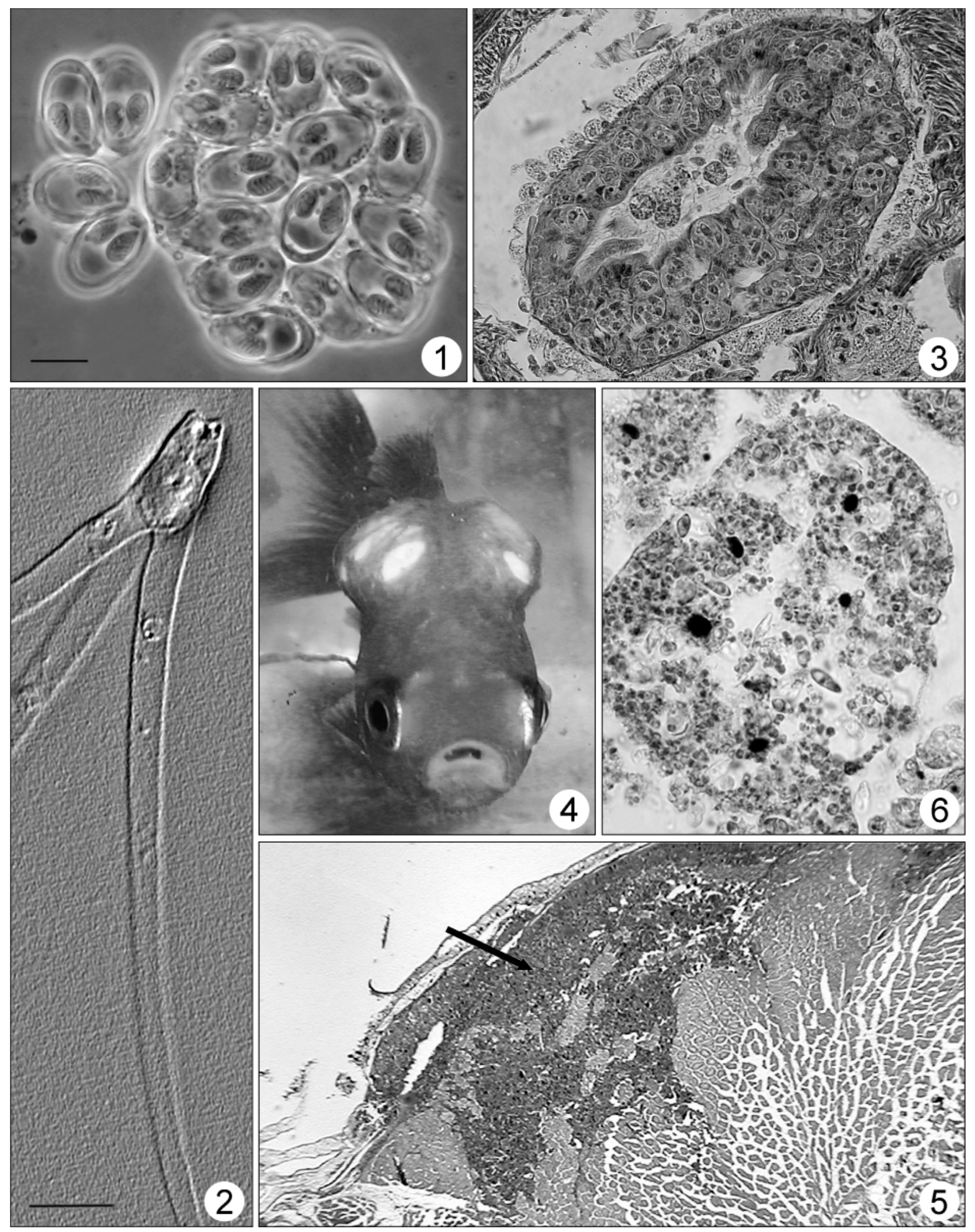

Figs. 1-6. Myxobolus lentisuturalis infection of the goldfish Carassius auratus auratus and of the oligochaete Branchiura sowerbyi. Fig. 1. Myxospores, frontal view; phase contrast (scale bar $=6 \mu \mathrm{m})$. Fig. 2. Raabeia-type actinospore; fresh mount (scale bar $=14$ $\mu \mathrm{m})$. Fig. 3. Cross-section through the intestine of an infected B. sowerbyi. Pansporocysts in the intestinal epithelium. H\&E, $\times 250$. Fig. 4. Goldfish infected by M. lentisuturalis. Note the dorsolateral humps. Fig. 5. Cross-section through the dorsal epaxial muscle of goldfish infected by $M$. lentisuturalis. Arrow - muscle fibres containing spores. PAS, $\times 60$. Fig. 6. Higher magnification of the same. Pseudocyst filled with M. lentisuturalis plasmodium. Crossmon's trichrome, $\times 450$. 
sowerbyi, commencing 15 days post-collection from the farm and continuing for almost 60 days. The spore had a slightly elongated body and 3 relatively long, pointed and curved caudal processes without a style. The caudal processes were $196(183-218 \pm 11)$ long, the spore body length was $22.1(18.1-28.2 \pm 3.9)$ and the width was 10.8 (7.9-14.0 \pm 1.8$)$. Three pyriform polar capsules situated at the top of spore body were $4.7(3.8-5.0 \pm 0.7)$ in length and $2.9(2.4-2.9 \pm 0.5)$ in width. The polar filaments were coiled 3-4 times. The morphology and morphometry $(\mathrm{n}=20$ from one worm) of the actinospores collected are consistent with Raabeia type Janiszewska, 1955. Histological examination of the Raabeia-infected $B$. sowerbyi disclosed pansporocysts in the intestinal epithelium (Fig. 3).

\section{SSU rRNA analysis}

The SSU rRNA from all 10 myxospore clones amplified with the universal primers resulted in a $2090 \mathrm{bp}$ fragment. The consensus sequence fragment analyzed by BLAST search gave $99.8 \%$ identity with $M$. lentisuturalis from China (AY119688 - Dyková et al. 2002).

Eight out of the 10 actinospore clones sequenced showed $100 \%$ identity with $M$. lentisuturalis from Italy (AY278563.2) while 2 clones showed 99.7\% identity with M. cultus (AB121146).

Table 2 shows the percentage of identical base pairs of the approximately $850 \mathrm{bp}$ of the SSU rRNA sequence from all Raabeia-type actinospores available in GenBank.

Table 2. Percentage of identical base pairs in the Raabeia-type actinospore sequences available, comparing an approximate 840 bp fragment of $18 \mathrm{~S}$ rDNA.

\begin{tabular}{ccccccccc}
\hline & 1 & 2 & 3 & 4 & 5 & 6 & 7 & 8 \\
\hline 1 & 100 & & & & & & & \\
2 & 48.7 & 100 & & & & & & \\
3 & 51.6 & 55.5 & 100 & & & & & \\
4 & 65.1 & 52.8 & 57.3 & 100 & & & & \\
5 & 51.3 & 93.9 & 56.5 & 50.7 & 100 & & & \\
6 & 93.7 & 46.1 & 48.4 & 62.2 & 50.3 & 100 & & \\
7 & 99.4 & 48.7 & 50.7 & 65.1 & 50.1 & 92.9 & 100 & \\
8 & 99.5 & 49.5 & 51.5 & 65.0 & 50.8 & 93.4 & 99.6 & 100 \\
\hline
\end{tabular}

[1] Raabeia EE 2005 (DQ231142 - Eszterbauer et al. 2006); [2] Raabeia type 3 (AJ582009 - Holzer et al. 2004); [3] Raabeia type 4 (AJ582010 Holzer et al. 2004); [4] Raabeia type 1 (AJ582008 - Holzer et al. 2004); [5] Raabeia type 1 (AY495709 - Hallet et al. 2006); [6] Raabeia (M. lentisuturalis type, present study); [7] Raabeia (M. cultus type, present study); [8] Raabeia (M. cultus AB121146 - Iwashita and Yokoyama, unpubl.).

\section{Histology}

The 28 fish with conspicuous humps on the dorsolateral side, just behind the head (Fig. 4), showed no other clinical signs of infection. Histological examination at low magnification showed the presence, in cross-section, of two bilateral crescent-shaped masses, in the dorsal epaxial muscle (Fig. 5). These lesions were not circumscribed, presented irregular edges and infiltrated the un- derlying bundles of skeletal muscle and interstitial tissue. The muscle fibres within the masses were strongly altered. At higher magnification, disappearance of muscle fibres and substitution of the muscle tissue with Myxobolus spores and plasmodia, grouped in pseudocysts, were observed (Fig. 6). In advanced infections, the muscle cells were necrotic with pycnotic and hypertrophic nuclei, and the tissue was infiltrated with scattered lymphocytes and macrophages as described by Dyková et al. (2002). In some cases, at the border of the lesion, the muscular tissue appeared atrophic with hyaline necrosis and slight inflammation with the presence of lymphocytes and macrophages. Some Ziehl-Neelsen negative granulomatous lesions, of unclear etiology, with necrotic foci were also observed scattered between the muscle fibres. In other cases, also the dermis was filled with parasites at various stages of development as well as lymphocytes and plasma cells. In a few cases, spores at different stages of differentiation were evident within the collagen tissue of the dermis under the scales. Mature spores and melanomacrophages were noticed in contact with the vertebrae, within the loose collagenous tissue next to the blood vessels and spinal nerves. Rodlet cells were detected in the vessel walls. Other groups of mature spores embedded in melanomacrophage centres were found outside the head kidney, adjacent to the vertebrae. No spores were observed in the melanomacrophage centres of parenchymatous organs or in gills, intestine, brain or gall bladder, unlike the findings of Dyková et al. (2002).

\section{DISCUSSION}

Myxobolus lentisuturalis is a little known myxozoan parasite that infects piscine skeletal muscles. It was described for the first time by Dyková et al. (2002) in Prussian carp (Carassius gibelio) from China. These authors gave no information on this myxosporean's extrapiscine development.

The Myxobolus species found in goldfish (Carassius auratus auratus), farmed in Italy, is most consistent morphologically and molecularly with $M$. lentisuturalis described by Dyková et al. (2002). The myxospores are identical except for some minor morphometric discrepancies; the spores described by Dyková et al. (2002) are bigger in all dimensions. The sequence obtained by the amplification of the SSU rRNA (AY278563.2) showed 99.8\% identity with M. lentisuturalis (AY119688), confirming the previously reported variability of spores collected from different fish hosts sharing the genotype but showing differences in the phenotype (Holzer et al. 2004).

The actinospore stages released by the oligochaete, Branchiura sowerbyi, were phenotypically compatible with Raabeia-type spores described by other authors, but possessed at least one different characteristic. The morphology and morphometry of the Italian Raabeia type are consistent with: Raabeia type 4 of El-Mansy et al. (1998) 
except that the polar capsules of the former are smaller $(5.7 \times 4$ vs $4.7 \times 2.9)$; Raabeia described by Eszterbauer et al. (2006) in which, however, the caudal processes are slightly shorter (190 vs 204); Raabeia type B-C-D reported by Xiao and Desser (1998) and, in particular, type D which is very similar morphologically except for its longer caudal process (290 vs 204); Raabeia type 3 of Özer et al. (2002) which was larger and showed $100 \%$ genetic identity with Myxobolus truttae (Holzer et al. 2004) on DNA; and Raabeia type 2 of Oumouna et al. (2002) which has a smaller spore body $(18 \times 15$ vs $22.1 \times 10.8)$ and a shorter caudal process ( 80 vs 204). The morphometry of our Raabeia and that of the Raabeia reported by Yokoyama et al. (1995) is very similar except for the shape of the spore body which is more cylindrical than rounded in the latter. This Raabeia from Japan was collected from $B$. sowerbyi and has been identified from an experimental infection of goldfish as the actinospore stage of Myxobolus cultus (Yokoyama et al. 1995). In a later study, Eszterbauer et al. (2006) identified similar actinospores at the DNA level and found out their $99.4 \%$ similarity with M. cultus (AB121146).

The SSU rRNA sequence of the Raabeia-type actinospores from Italy reveals $100 \%$ identity with M. lentisuturalis (AY278563.2) myxospores from goldfish farmed in Italy, indicating the involvement of B. sowerbyi in the life cycle of this Myxobolus species. Based on the SSU rRNA sequences, we were able to demonstrate that the life cycle of $M$. lentisuturalis involves two distinct types of spore stages: Myxobolus myxospores from hump lesions on the dorsolateral side of the head in goldfish, and Raabeia actinospores released by the oligochaete Branchiura sowerbyi.

In 2 of the 10 SSU rRNA clones obtained from the actinospore DNA sample, the sequence had $99.7 \%$ identical base pairs to that of the Raabeia type identified by Eszterbauer et al. (2006) as the actinosporean stage of M. cultus (AB121146). This suggests that the oligochaete population in the goldfish pond was naturally infected with more than one type of actinospore.

The identification of the actinospores should not be based only on morphology, as already suggested by several authors (El-Mansy et al. 1998, Hallett et al. 1999, Kent et al. 2001, Negredo et al. 2003, Eszterbauer et al. 2006), for the possibility of multiple infections in oligochaetes and the similarity of the actinospores of different myxosporeans (as pointed out in the differential diagnosis above). In our survey, the morphology and morphometry of the Raabeia-type spore detected and measured were referable to a single type, identified as the actinosporean stage of $M$. lentisuturalis and morphologically different from the Raabeia-type spore described by Yokoyama et al. (1995) as the actinosporean stage of M. cultus. This latter type was detected only after cloning the PCR product from a pool of spores from the same worm. This points out the importance of approaching the diagnosis by combining traditional parasitological methods with molecular techniques and, in particular, the advantages of cloning the PCR product and then sequencing rather than obtaining direct sequences from the PCR products.

None of the goldfish examined had cysts in their cartilage tissue, the primary site of infection by $M$. cultus, but the finding of the actinospore stage of this myxozoan indicates that this species is present in ponds, despite never been detected in goldfish farmed in Italy.

In this study, a natural infection of the oligochaete, Branchiura sowerbyi, by the Raabeia-type actinosporean stage of $M$. lentisuturalis was detected by molecular analysis, showing that this parasite's life-cycle follows the same pattern as that described for $M$. cerebralis by Wolf and Markiw (1984). Although the entire developmental cycle was not followed because no experimental infections were performed, comparison of the SSU rRNA sequence of the myxospore stage from goldfish with that of the actinospore stage from $B$. sowerbyi demonstrates that they are, in fact, the same species. This approach has also been used for linking the life-cycle stages for other freshwater myxozoans (Andree et al. 1997, Bartholomew et al. 1997, Lin et al. 1999, Longshaw et al. 1999, Pote et al. 2000).

The goldfish examined originate from a farm where no new fish have been introduced for several years and where a similar syndrome had not previously been observed. We could only hypothesize the introduction of actinospores by way of water inasmuch as the goldfish farm is fed by a channel where wild cyprinids live and into which other fish farms discharge.

Further experiments are required in order to complete the life cycle of $M$. lentisuturalis to demonstrate that Raabeia actinospores transform into $M$. lentisuturalis myxospores in goldfish. However, the current study suggests that these are alternating stages of the same myxozoan species. This species is reported for the first time from goldfish and from Italy. In addition, although $M$. cultus was not found in goldfish in our surveys, the identification of the rDNA of this species in actinospores released from oligochaetes provides evidence of its presence in the Italian farm surveyed.

Acknowledgements. We wish to thank Dr. Oswaldo Palenzuela, Instituto de Acuicultura de Torre de la Sal, Castellon, Spain for his valuable contribution to this paper. 


\section{REFERENCES}

Altschul S.F., Gish W., Miller W., Myers E.W., Lipman D.J. 1990: Basic local alignment search tool. J. Mol. Biol. 215: 403-410.

Anderson C.L., Canning E.U., Okamura B. 1999: Molecular data implicate bryozoans as hosts for PKX (phylum Myxozoa) and identify a clade of bryozoan parasites within the Myxozoa. Parasitology 119: 555-561.

Anderson C.L., Canning E.U., Schaefer S.M., Yokoyama H., OKamura B. 2000: Molecular confirmation of the life cycle of Thelohanellus hovorkai Achmerov, 1960 (Myxozoa: Myxosporea). Bull. Eur. Assoc. Fish Pathol. 20: 111-115.

Andree K.B., Gresoviac S.J., Hedrick R.P. 1997: Small subunit ribosomal sequences unite actinosporean and myxosporean stages of Myxobolus cerebralis, the causative agent of whirling disease in salmonid fishes. J. Eukaryot. Microbiol. 44: 208-215.

Atkinson S.D., Hallett S.L., Bartholomew J.L. 2007: The life cycle of Chloromyxum auratum (Myxozoa) from goldfish, Carassius auratus (L.), involves an antonactinomyxon actinospore. J. Fish Dis. 30: 149-156.

Bartholomew J.L., Atkinson S.D., Hallett S.L. 2006: Involvement of Manayunkia speciosa (Annelida: Polychaeta: Sabellidae) in the life cycle of Parvicapsula minibicornis, a myxozoan parasite of pacific salmon. J. Parasitol. 92: 742-748.

Bartholomew J.L., Whipple M.J., Stevens D.G., Fryer J.L. 1997: The life cycle of Ceratomyxa shasta, a myxosporean parasite of salmonids, requires a freshwater polychaete as an alternate host. J. Parasitol. 83: 859-868.

BrinkHurst R.O., JAMIESON B.G.M. 1971: Aquatic Oligochaeta of the World. Oliver \& Boyd, Edinburgh, 860 pp.

Dyková I., Fiala I., Nie P. 2002: Myxobolus lentisuturalis sp. n. (Myxozoa: Myxobolidae), a new muscle-infecting species from the Prussian carp, Carassius gibelio from China. Folia Parasitol. 49: 253-258.

El-Mansy A., Molnár K. 1997a: Extrapiscine development of Myxobolus drjagini Akhmerov, 1954 (Myxosporea: Myxobolidae) in oligochaete alternate hosts. Acta Vet. Hung. 45: 427-438.

El-Mansy A., Molnár K. 1997b: Development of Myxobolus hungaricus (Myxosporea: Myxobolidae) in oligochaete alternate hosts. Dis. Aquat. Org. 31: 227-232.

El-Mansy A., Molnár K., Székely C. 1998: Development of Myxobolus portucalensis Saraiva \& Molnár, 1990 (Myxosporea: Myxobolidae) in the oligochaete Tubifex tubifex (Müller). Syst. Parasitol. 41: 95-103.

El-Mansy A., Székely C., Molnár K. 1998: Studies on the occurrence of actinosporean stages of fish myxosporeans in a fish farm of Hungary, with the description of triactinomyxon, raabeia, aurantiactinomyxon and neoactinomyxum types. Acta Vet. Hung. 46: 259-284.

El-Matbouli M., Hoffmann R.W. 1989: Experimental transmission of two Myxobolus spp. developing bisporogeny via tubificid worm. Parasitol. Res. 75: 461-464.

El-Matbouli M., Hoffmann R.W. 1993: Myxobolus carassii Klokaceva, 1914 also requires an oligochaete, Tubifex tubifex, as intermediate host in its life cycle. Bull. Eur. Assoc. Fish Pathol. 13: 189-192.

Embley T.M., Finlay B.J., Thomas R.H., Dyal P.L. 1992: The use of rRNA sequences and fluorescent probes to investigate the phylogenetic position of the anaerobic ciliate Metopus palaeformis and its archaeobacteria endosymbiont. J. Gen. Microbiol. 138: 1479-1487.
Eszterbauer E., Marton S., Rácz O.Z., Letenyei M., Molnár K. 2006: Morphological and genetic differences among actinosporean stages of fish-parasitic myxosporeans (Myxozoa): difficulties of species identification. Syst. Parasitol. 65: 97-114.

Eszterbauer E., Székely C., Molnár K., Baska F. 2000: Development of Myxobolus bramae (Myxosporea: Myxobolidae) in an oligochaete alternate host, Tubifex tubifex. J. Fish Dis. 23: 19-25.

Hallett S.L., Atkinson S.D., Erséus C., El-Matbouli M. 2006: Myxozoan parasites disseminated via oligochaete worms as live food for aquarium fishes: descriptions of aurantiactinomyxon and raabeia actinospore types. Dis. Aquat. Org. 69: 213-225.

Hallett S.L., Erséus C., Lester R.J.G. 1999: Actinosporeans (Myxozoa) from marine oligochaetes of the Great Barrier Reef. Syst. Parasitol. 44: 49-57.

Holzer A.S., Sommerville C., Wootten R. 2004: Molecular relationship and phylogeny in a community of myxosporean and actinosporean based on their $18 \mathrm{~S}$ rDNA sequences. Int. J. Parasitol. 34: 1099-1111.

Kallert D.M., Eszterbauer E., Erséus C., El-Matbouli M., HaAs W. 2005: Life cycle studies of Myxobolus parviformis sp. n. (Myxozoa: Myxobolidae) from bream. Dis. Aquat. Org. 66: 233-243.

Kent M.L., Andree K.B., Bartholomew J.L., El-Matbouli M., Desser S.S., Devlin R.H., Feist S.W., Hedrick R.P., Hoffman R.W., Khattra J., Hallett S.L., Lester R.J.G., LongShaw M., Palenzuela O., Siddall M.E., Xiao C. 2001: Recent advances in our knowledge of the Myxozoa. J. Eukaryot. Microbiol. 48: 395-413.

Kent M.L., Khattra J., Hedrick R.P. Devlin R.H. 2000: Tetracapsula renicola $\mathrm{n}$. sp. (Myxozoa: Saccosporidae); the PKD myxozoan - the cause of proliferative kidney disease of salmonid fishes. J. Parasitol. 86: 103-111.

Kent M.L., Whitaker D.J., Margolis L. 1993: Transmission of Myxobolus arcticus Pugachev and Khokhlov, 1979, a myxosporean parasite of Pacific salmon, via a triactinomyxon from the aquatic oligochaete Stylodrilus heringianus (Lumbriculidae). Can. J. Zool. 71: 1207-1211.

Køie M., Karlsbakk E., Nylund A. 2007: A new genus Gadimyxa with three new species (Myxozoa, Parvicapsulidae) parasitic in marine fish (Gadidae) and the two-host life cycle of Gadimyxa atlantica n. sp. J. Parasitol. 93: 1459-1467.

Køie M., Karlsbakk E., Nylund A. 2008: The marine herring myxozoan Ceratomyxa auerbachi (Myxozoa: Ceratomyxidae) uses Chone infundibuliformis (Annelida: Polychaeta: Sabellidae) as invertebrate host. Folia Parasitol. 55: 100-104.

Køie M., Whipps C.M., Kent M.L. 2004: Ellipsomyxa gobii (Myxozoa: Ceratomyxidae) in the common goby Pomatoschistus microps (Teleostei: Gobiidae) uses Nereis spp. (Annelida: Polychaeta) as invertebrate hosts. Folia Parasitol. 51: 14-18.

Lin D., Hanson L.A., Pote L.M. 1999: Small subunit ribosomal RNA sequence of Henneguya exilis (class Myxosporea) identifies the actinosporean stage from an oligochaete host. J. Eukaryot. Microbiol. 46: 66-68.

Lom J., Arthur J.R. 1989: A guideline for the preparation of species description in Myxosporea. J. Fish Dis. 12: 151-156.

Lom J., Dyкоvá I. 2006: Myxozoan genera: definition and notes on taxonomy, life-cycle terminology and pathogenic species. Folia Parasitol. 53: 1-36.

Longshaw M., Feist S.W., Canning E.U., Okamura B. 1999: First identification of PKD in bryozoans from the United King- 
dom - molecular evidence. Bull. Eur. Assoc. Fish Pathol. 19: 146-148.

Marcer F., Fioravanti M.L., Caffara M., Delgado M.L., FloRio D., Restani R. 2000: Ricerche parassitologiche in pesci rossi (Carassius auratus) allevati in Emilia-Romagna. Boll. Soc. It. Patol. Ittica 32: 35-46.

Molnár K., El-Mansy A., Székely C., Baska F. 1999: Development of Myxobolus dispar (Myxosporea: Myxobolidae) in an oligochaete alternate host, Tubifex tubifex. Folia Parasitol. 46: $15-21$.

Negredo C., Dillane E., Mulcahy M.F. 2003: Small subunit ribosomal DNA characterization of an unidentified aurantiactinomyxon form and its oligochaete host Tubifex ignotus. Dis. Aquat. Org. 54: 229-241.

Oumouna M., Hallett S.L., Hoffmann R.W., El-Matbouli M. 2002: Early developmental stages of two actinosporean, Raabeia and Aurantiactinomyxon (Myxozoa), as detected by light and electron microscopy. J. Invertebr. Pathol. 79: 17-26.

Özer A., Wootten R., Shinn A.P. 2002: Survey of actinosporean types (Myxozoa) belonging to seven collective groups found in a freshwater salmon farm in Northern Scotland. Folia Parasitol. 49: 189-210.

Pote L.M., Hanson L.A., Shivaji R. 2000: Small subunit ribosomal RNA sequences link the cause of proliferative gill disease in channel catfish to Henneguya ictaluri (Myxozoa: Myxosporea). J. Aquat. Anim. Health 12: 230-240.

Ruidisch S., El-Matbouli M., Hoffman R.W. 1991: The role of tubificid worms as an intermediate host in the life cycle of Myxobolus pavlovskii (Achmerov, 1954). Parasitol. Res. 77: 663-667.

Received 17 June 2008
SzÉKely C., MolnÁr K., RÁcz O. 2001: Complete developmental cycle of Myxobolus pseudodispar (Gorbunova) (Myxosporea: Myxobolidae). J. Fish Dis. 24: 461-468.

Székely C., Rácz O. Molnár K., Eszterbauer E. 2002: Development of Myxobolus macrocapsularis (Myxosporea: Myxobolidae) in an oligochaete alternate host, Tubifex tubifex. Dis. Aquat. Org. 48: 117-123.

Urawa S. 1994: Life cycle of Myxobolus arcticus, a myxosporean parasite of salmonid fishes. Int. Symp. Aquat. Anim. Health, Seattle 4-8 Sept. 1994, Program and Abstracts, p. W-10.3.

Wolf K., Markiw M.E. 1984: Biology contravenes taxonomy in the Myxozoa: new discoveries show alternation of invertebrate and vertebrate hosts. Science 225: 1449-1452.

Xiao C.X., Desser S.S. 1998: Actinosporean stages of myxozoan parasites of oligochaetes from Lake Sasajewun, Algonquin Park, Ontario: new forms of triactinomyxon and raabeia. J. Parasitol. 84: 998-1009.

Yokoyama H., Ogawa K., Wakabayashi H. 1991: A new collection method of actinosporeans - a probable infective stage of myxosporeans to fishes - from tubificids and experimental infection of goldfish with the actinosporean Raabeia sp. Fish Pathol. 26: $133-138$.

Yokoyama H., Ogawa K., Wakabayashi H. 1995: Myxobolus cultus n. sp. (Myxosporea: Myxobolidae) in the goldfish Carassius auratus transformed from the actinosporean stage in the oligochaete Branchiura sowerbyi. J. Parasitol. 81: 446-451.

Accepted 11 November 2008 